\title{
Diatom identification in the face of changing species concepts and evidence of phenotypic plasticity
}

\author{
EILEEN J. COX \\ The Natural History Museum, Cromwell Road, London SW7 5BD, UK \\ (e-mail: e.j.cox@nhm.ac.uk)
}

\begin{abstract}
Although it is often suggested that diatom wall morphology is faithfully replicated at each cell division, it is also well known that the average cell size of a diatom population usually decreases as cells proliferate. Comparisons between the two valves of a single frustule may also reveal morphological differences, indicating that valve ontogenetic processes are susceptible to modification. This paper will discuss the different factors affecting valve morphology in diatoms and some of the implications for ecological and palaeo-ecological studies using diatoms. It will also consider some of the problems of evaluating variation between clonal populations, and the influence of findings from molecular biology and reproductive studies on the interpretation of morphology and species concepts.
\end{abstract}

KEYWORDS: species concepts, environmental variability, diatom life history, clonal populations, diatom identification

\section{INTRODUCTION}

Diatoms are well known for their regularly patterned siliceous cell walls (frustules) and the apparent fidelity with which wall construction is replicated at each cell division, yet it is also known that morphological changes can occur as cell size decreases, following successive vegetative divisions. In addition, examples of heterovalvy, when the two halves (valves) of a single frustule differ morphologically (apart from the monoraphid diatoms, which are inherently heterovalvate), can be found in the literature (Stoermer, 1967; Jordan et al., 1991; Teubner, 1995; Meyer \& Håkansson, 1996; McBride \& Edgar, 1998; Werner \& Smol, 2006), indicating that ontogenetic processes during wall formation may be modified by external factors. The existence of contrasting linkage and separation (or intercalary and terminal) valves in some chain-forming diatoms, summer and winter stages in others, or the formation of resting spores in neritic species, also indicates that a single genotype can have more than one morphological expression (Fryxell, 1978; Crawford, 1979; Fryxell \& Prasad, 1990; Bentley et al., 2012). Although results of molecular studies of diatoms are challenging some traditional interpretations of diatom relationships, as well as species concepts (e.g. Mann, 1999; Mann et al., 2004; Kaczmarska et al., 2013), for most ecological and palaeo-ecological studies, taxon identification still rests heavily on the morphology of the siliceous walls under light microscopy. Furthermore, inferring ecological conditions from diatom assemblages relies on known correlations between species occurrences and environment, assuming consistent identification of the taxa. It is therefore important to know to what extent morphology is consistent within a taxon, what changes may occur during size reduction and what effects environment can have on the morphology of a particular taxon.

This paper will consider some of the issues raised by changes in diatom species concepts based on reproductive and molecular studies on the one hand, and challenges to traditional species definitions from evidence of phenotypic plasticity (the ability of an organism to change its phenotype in response to environmental changes) on the other. What does this mean for palaeontologists and palaeo-ecologists who must rely on morphological evidence for taxon identification? It will also consider whether subtler influences affect the interpretation of morphological evidence. Does the fact that diatom assemblages in any one sample (representing a short time-scale, days or weeks) are usually represented by clonal populations (at least in contemporary samples), each comprising many cells of identical genotype and very similar morphology, affect how the observer interprets the significance of morphological variation between populations at different sites? (Fossil assemblages can represent much longer time periods of accumulation, which may then include a range of populations and morphologies, but whether this inevitably results in wider species concepts is uncertain.) In addition, to what extent do developments in one research area impinge on another, subtly shifting paradigms and concepts by inference rather than by evidence?

\section{DIATOM WALL FORMATION AND LIFE HISTORIES}

One of the distinctive characteristics of diatoms is their cell wall construction and mode of formation. With few exceptions, all diatom cell walls essentially comprise two larger siliceous components (valves) with a series of linking elements (girdle bands) (Fig. 1), which are external to the protoplast, although variously anchored to the latter when alive (Round et al., 1990; Cox, 2011). Following mitosis, new valves are generated in membrane-bound vesicles inside the daughter cells, being released to the exterior on completion (Fig. 2). Thus the valves of a single cell are not formed simultaneously, but each cell comprises an older (epi-) and a younger (hypo-) valve (Fig. 1). Girdle band formation occurs over the life of a cell, bands being added sequentially to the hypovalve until just before the next mitosis (Pickett-Heaps et al., 1990; Round et al., 1990; Cox, 2012). Once valves are formed and released their size is fixed; cell volume increases only by the addition of more girdle bands and expansion of the cell in the pervalvar direction. As the bands are also siliceous, there is little flexibility in the diatom frustule, constraining the space in which new valves can be formed after cell division. Depending on the thickness and rigidity of the cell wall (particularly in the 


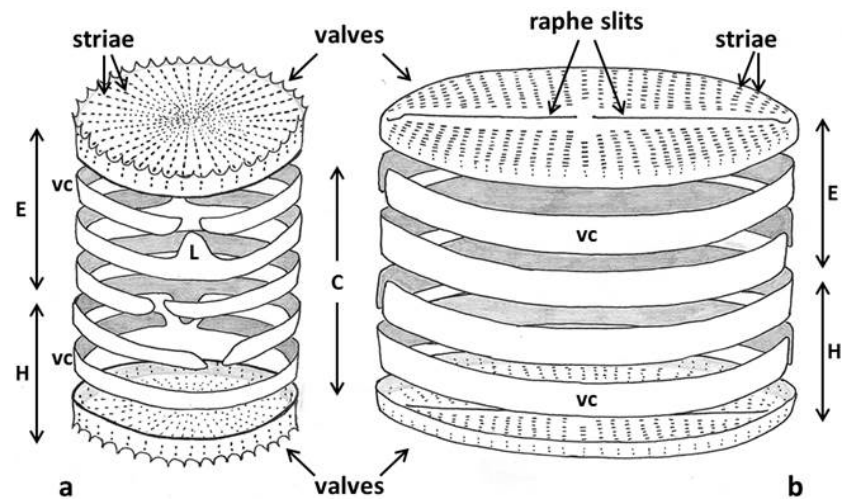

Fig. 1. Diagrams showing the basic cell wall structure of (a) a radial centric and (b) a raphid pennate diatom. Each frustule comprises two thecae, an older epitheca (E) and younger hypotheca $(\mathrm{H})$, each comprising a valve with a series of girdle bands (cingulum, C). Rows of pores (striae) are radially oriented on centric diatoms (a), about a longitudinal axis of symmetry in pennate (b) diatoms. Raphid diatoms are characterized by the presence of paired raphe slits through the valve, enabling the diatom to move over surfaces. Girdle bands are often split rings, sometimes with a tongue-like extension (ligula, L) that inserts between the ends of the adjacent band. The band nearest the valve is usually designated the valvocopula (vc). Spines may be present around the periphery of a valve.

girdle region), new valves may therefore be more or less markedly smaller than the parent valves (Crawford, 1981).

Although there are some diatoms that show no size reduction over time (Rose \& Cox, 2013), in most cases, a sexual reproductive phase followed by cell expansion (auxosporulation) (Figs $3-4)$, is necessary to prevent populations dying out as size reduction proceeds (Round et al., 1990; Mann, 2011; Kaczmarska et al., 2013). After expansion within some sort of lightly protected structure (perizonium, incunabulum, properizonium), new valves are laid down and vegetative division proceeds again. The firstformed (initial) valves are usually somewhat atypical, in part at least because they are not formed within the constraints of a normal frustule, juxtaposed to a sibling valve. Thus, initial valves of radial centric diatoms may be hemispherical, while those of pennate diatoms have a convex rather than flattened valve face and some may be inflated at the centre (Cohn et al., 1989; Assmy et al., 2006), reflecting the perizonium shape. It has also been suggested that valve features, such as stria arrangements, may be atypical because full cytoskeletal control of morphogenesis, which determines the positioning of some wall structures, is not re-established until the first vegetative division (Pickett-Heaps et al., 1990; Schmid 1994, Cox, 2002).

\section{CONSISTENCY IN DIATOM STRUCTURE}

While cell size and shape are subject to variation over the life cycle of particular diatom species, within any taxon the component parts of a frustule (processes [Fig. 5a], spines [Fig. 5b, c], girdle bands [Fig. 5c-e], striae [Fig. 5a, b, e-h], raphe [Fig. 5f-h]) (Fig. 1) are always formed in the same way and, therefore, have a consistent ultrastructure (Cox, 2011, 2012). Thus, species within a genus will be expected to share the same type of pore structure, e.g., poroid with cribrate occlusions, poroid with hymenate occlusions, loculate with external cribrate occlusions (Fig. 5e), loculate with internal hymenate occlusions (Round et al., 1990; Cox, 2011), although some genera do not meet this requirement because they have been only partially revised (e.g. Navicula Bory sensu lato, Triceratium Ehrenberg sensu lato). Cingulum construction is similarly consistent within taxa, e.g. bands are with or without pores that are in turn occluded by cribra or hymenes; bands are with or without septa, are complete or split, etc. (Pocock \& Cox, 1982; Round et al., 1990; Cox, 2011 and references therein). Other fundamental characteristics of the cell wall show comparable consistency within taxa. Features associated with particular functions, e.g. apical pore fields through which polysaccharide pads or stalks are secreted, or raphe slits associated with motility, are also generally unchanged throughout the life cycle. On the other hand, stria arrangements may be more susceptible to modification, spacing varying within a certain range, as cell dimensions change. Thus, stria density within a clone will gradually increase with decreasing cell length, then

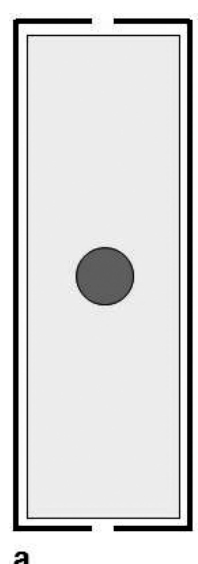

a

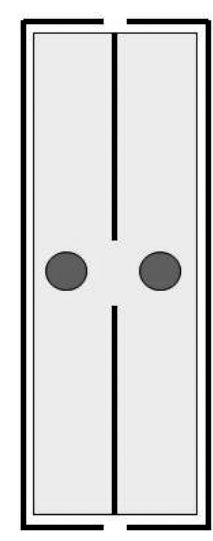

b
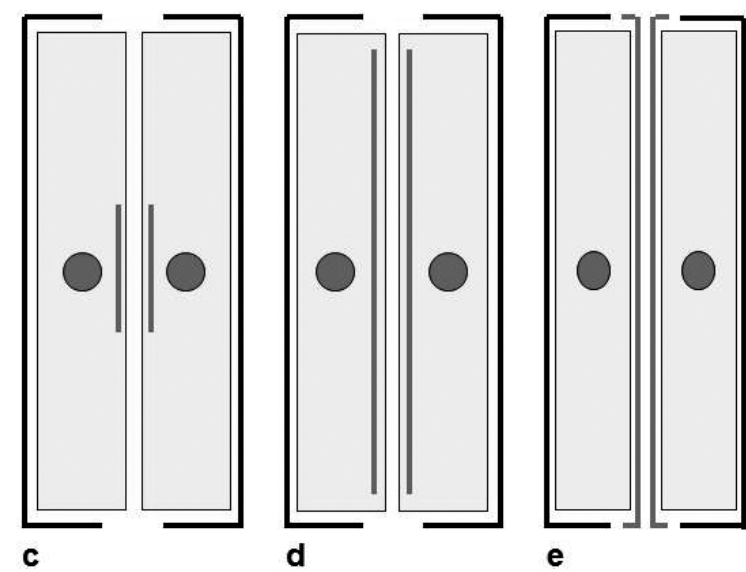

Fig. 2. Diagram showing process of vegetative cell division and formation of new valves. (a) vegetative cell; (b) cytokinesis proceeding after mitosis; (c) formation of new valves beginning at centre; (d) new valve formation continuing; (e) new valves completed and released to exterior. Thick black outer lines represent the valves (in girdle view), paler thick lines show the forming hypovalves, which are laid down within a membrane-bound vesicle inside the daughter cells, only released to the exterior after completion. Nuclei represented by grey circles. 


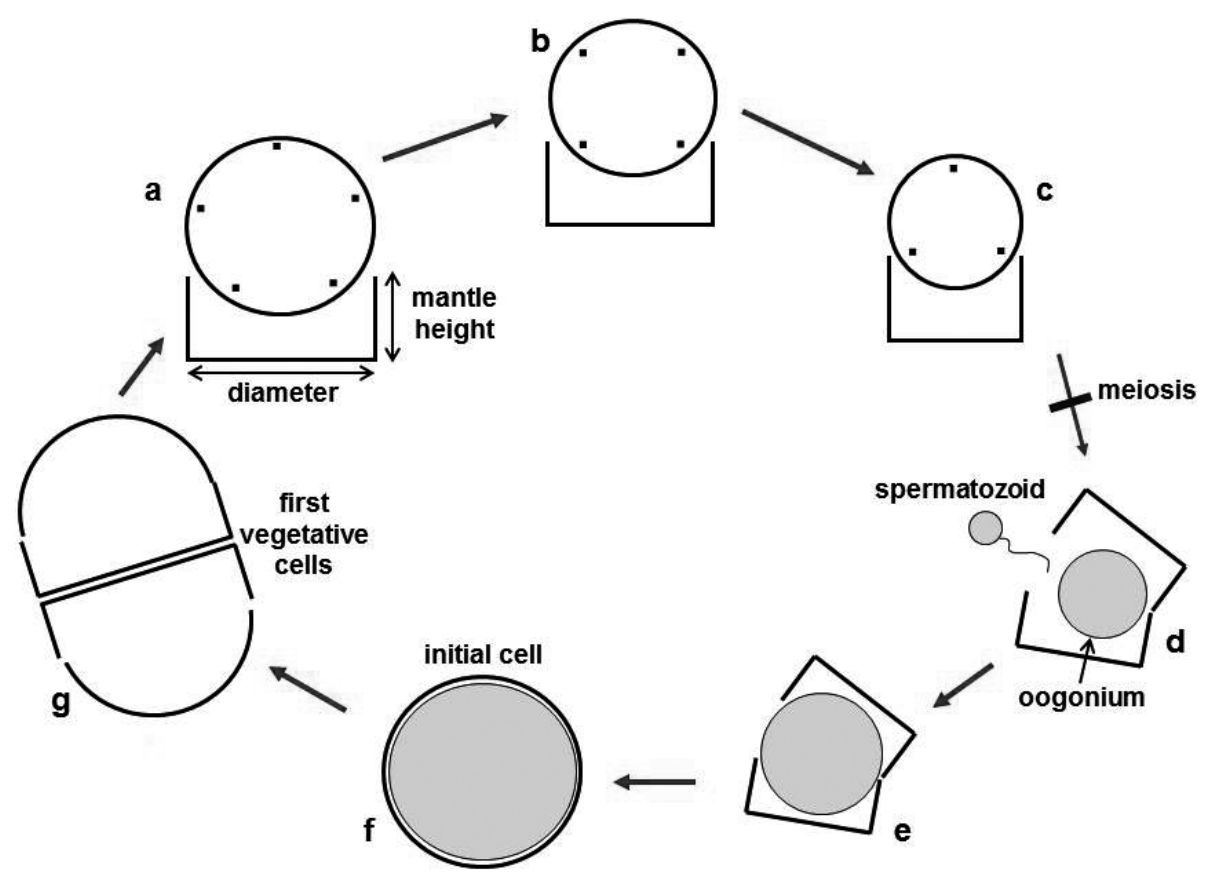

Fig. 3. Diagram summarizing typical life cycle of an oogamous (usually centric) diatom. (a-c) Valve diameter decreases over a series of vegetative divisions, peripheral processes (shown as dots) may decrease in number with decreasing diameter, while diameter: mantle height ratio changes. (d) Meiosis occurs to produce oogonium and flagellate spermatozoa. (e-f) Following gametic fusion, zygote (auxospore) expands to maximum size and (f) deposits new walls externally. (g) Initial cells are often more or less spherical, first vegetative cells are often heterovalvate with an initial valve and a 'normal' vegetative valve. Non-silicified stages are shown with a thin line, siliceous walls by thick black lines. Timing of meiosis indicated by arrow with transverse bar.

revert to a minimum before gradually increasing again, the cycle then repeating as cells continue to decrease in length (Cox, 1983); striae are packed slightly closer together before size restrictions preclude further packing and the number of striae in $10 \mu \mathrm{m}$ is reduced. Stria densities vary because units of fixed dimensions (pores) are being 'fitted into' changing areas. Similarly, if processes at the circumference of a round valve must have a minimum distance between them, their number per valve will be decreased if that valve decreases significantly in size (diameter and circumference) (Fig. 3).

Whereas electron microscopy (particularly SEM) reveals the 3D structure of diatom cell walls (Fig. 5a-h), this cannot always be determined with light microscopy (LM). Similar morphologies (in LM) could be generated from contrasting ultrastructural elements, e.g. longitudinal lines may mark the edge of internal alveolar openings (in Pinnularia Ehrenberg and Caloneis Cleve), longitudinal canals (in Neidium Pfitzer) or aligned gaps within striae (in Neidiopsis Lange-Bertalot \& Metzeltin) (Bahls, 2014). Similar morphologies under LM can also be generated by contrasting morphogenetic processes, e.g. stauros v. fascia (Cox, $2001,2002)$. It is also increasingly clear that shape and symmetry are not infallible guides to relationships at generic (Cox, 1979, 1982) or higher taxonomic levels (Cox, 2002; Kooistra et al., 2003; Alverson et al., 2006).

\section{INTRINSIC CHANGES IN DIATOM MORPHOLOGY}

I refer to changes that are a function of the life cycle of the diatom, unaffected by changing environment, as intrinsic. The effect of size reduction on diatom cell shape varies with the shape and symmetry of the taxon (taxon = any group of organisms considered a unit), as well as the depth and rigidity of the girdle region. Diatoms with circular valve faces (radial centrics) (Figs 1, 5a-c) do not change shape in valve view, although the cell proportions in girdle view may change because the cell diameter decreases but mantle depth does not (Fig. 3). This is most striking in diatoms such as Aulacoseira Thwaites and Melosira C. Agardh, in which valve diameter in large cells may be two or three times that of the smallest cells, seen most clearly when auxospores develop still associated with the original filament of small cells (Crawford, 1974, figs 5, 6). In multipolar diatoms the angularity of the valves may change, with angles becoming less acute as maximum diameter decreases. There is also some evidence that angles may be lost (e.g. Hydrosera Wallich - Cox, 2013, figs 2-7).

Although valve shape does not change in many radial centric diatoms, there can be changes in the relative proportions of central and peripheral areas. Thus, in some species, the size of marginal alveoli in Cyclotella (Kützing) Brébisson may remain approximately the same, but if valve diameter decreases, these occupy a larger proportion of the valve face in smaller than larger specimens (Prasad \& Nienow, 2006, figs 35-39). In other centrics the number of marginal processes may decrease with decreasing cell size (Fig. 3), if a minimum distance must be maintained between adjacent processes (Theriot \& Stoermer, 1981; Theriot, 1988; Beszteri et al., 2005).

In so-called bipolar centric and pennate diatoms, which both have a longer and a shorter valve axis (Fig. $5 \mathrm{~d}-\mathrm{h}$ ), size reduction is usually accompanied by a shift in valve proportions, length decreasing more than width; i.e. size reduction is allometric 


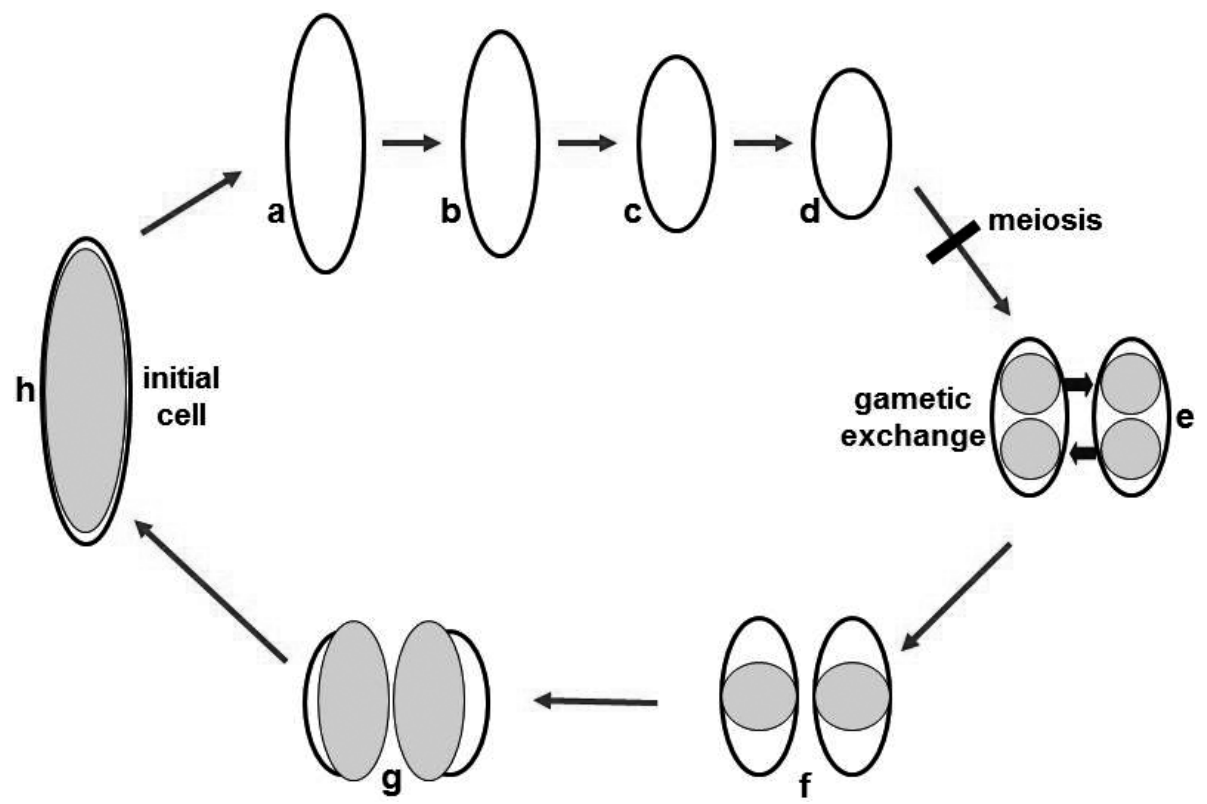

Fig. 4. Diagram summarizing the typical life cycle of an isogamous (usually pennate) diatom. (a-d) Valve length decreases over a series of vegetative divisions although valve width may remain more or less constant. Shape of valve therefore changes. Meiosis occurs when compatible cells pair, after which, (e-f) there is an exchange of gametes and fusion. The auxospore expands to its maximum size outside the confines of the parent valves (g) before (h) laying down new valves externally. Non-silicified stages are shown with a thin line, siliceous walls by thick black lines. Timing of meiosis indicated by arrow with transverse bar.

(Fig. 4) (Cox, 1985, 1986; Amato et al., 2005; D'Alelio et al., 2009). There may also be changes in the shape of the valve apices, which may become more rounded in some taxa, but in other cases, apical shape is maintained or even exaggerated (e.g. Geitler, 1932; Hustedt, 1955; Cox, 1986). Length reduction may also modify the proportional relationships of valve features, e.g. raphe length in Berkeleya rutilans (Trentepohl) Grunow remains more or less constant, but central area length decreases with decreasing valve length thereby changing raphe length: central area length ratio (Cox, 1975; Lobban, 1984). Meanwhile, in Donkinia Ralfs in Pritchard the central inflexion of the sigmoid raphe becomes sharper as valve length decreases (Cox, 1983). It is therefore impossible to make a simple generalization about shape changes with size reduction, or to be certain of the particular morphological changes within a taxon (species, variety) without following it for its entire life cycle, or at least being able to link the extremes of the cell size range (Hostetter \& Hoshaw, 1972; Steinman \& Sheath, 1984; Cox, 1985; Rose \& Cox in press). This also has implications when comparing different-sized specimens in samples from different locations, e.g. because of the interrelationship between raphe inflexion and valve length in Donkina lata E. J. Cox, different-sized cells looked rather different, although culture studies showed that they were part of same spectrum (Cox, 1983).

Legendre polynomial shape analysis has been used (Stoermer \& Ladewski, 1982; Stoermer et al., 1986) to compare presumed conspecific specimens from different samples/locations to assess the likelihood of conspecificity, or to explore variation within a single assemblage (Theriot \& Ladewski, 1986). It has also been applied to taxa which contain diverse forms (Rhode et al., 2001; Pappas \& Stoermer, 2003) to help evaluate the taxonomic status of different shape groups. Continuity in shape variation is interpreted as indicating that the specimens represent stages within the life cycle of a single species, whereas discontinuous shape variation may indicate the existence of discrete species (Pappas \& Stoermer, 2003). More recently, other morphometric studies have shown that shapes of apices and central areas in raphid diatoms are more informative than traditional size measures with respect to identity in morphologically similar taxa (Veselá et al., 2009).

\section{PHENOTYPIC RESPONSES TO EXTRINSIC FACTORS}

The intermittent occurrence of so-called Janus or heterovalvate diatom frustules (where the two valves in a single frustule are morphologically different) reveals the effect of changing environment on single genotypes (Stoermer, 1967; Jordan et al., 1991; Teubner, 1995; Meyer \& Håkansson, 1996; McBride \& Edgar, 1998; Werner \& Smol, 2006); i.e. diatoms are able to modify their wall morphology to a greater or lesser extent under different conditions. In the case of Gomphonema (McBride \& Edgar, 1998) the striae on one valve are much more closely spaced than on the other, while in Mastogloia Thwaites (Stoermer, 1967) the stria pattern was sufficiently different that the valves would be assigned to different species (Mastogloia grevillei W. Smith and M. elliptica var. dansei [Thwaites ex W. Smith] Cleve). The recognition of spring and winter forms in Proboscia Sundström and Eucampia antarctica (Castracane) Mangin indicates that different morphologies correlate with seasons (Fryxell, 1991, 1994; Jordan et al., 1991), while Chaetoceros dichaeta Ehrenberg produces cells with shorter setae in sea ice than in the plankton, and the setae are bent inside the filament rather than turning outwards (Ligowski et al., 2012). Meanwhile, the production of linkage and separation valves in some filamentous diatoms, e.g. Aulacoseira, Skeletonema Greville, Eucampia Ehrenberg, Cymatosira Grunow 

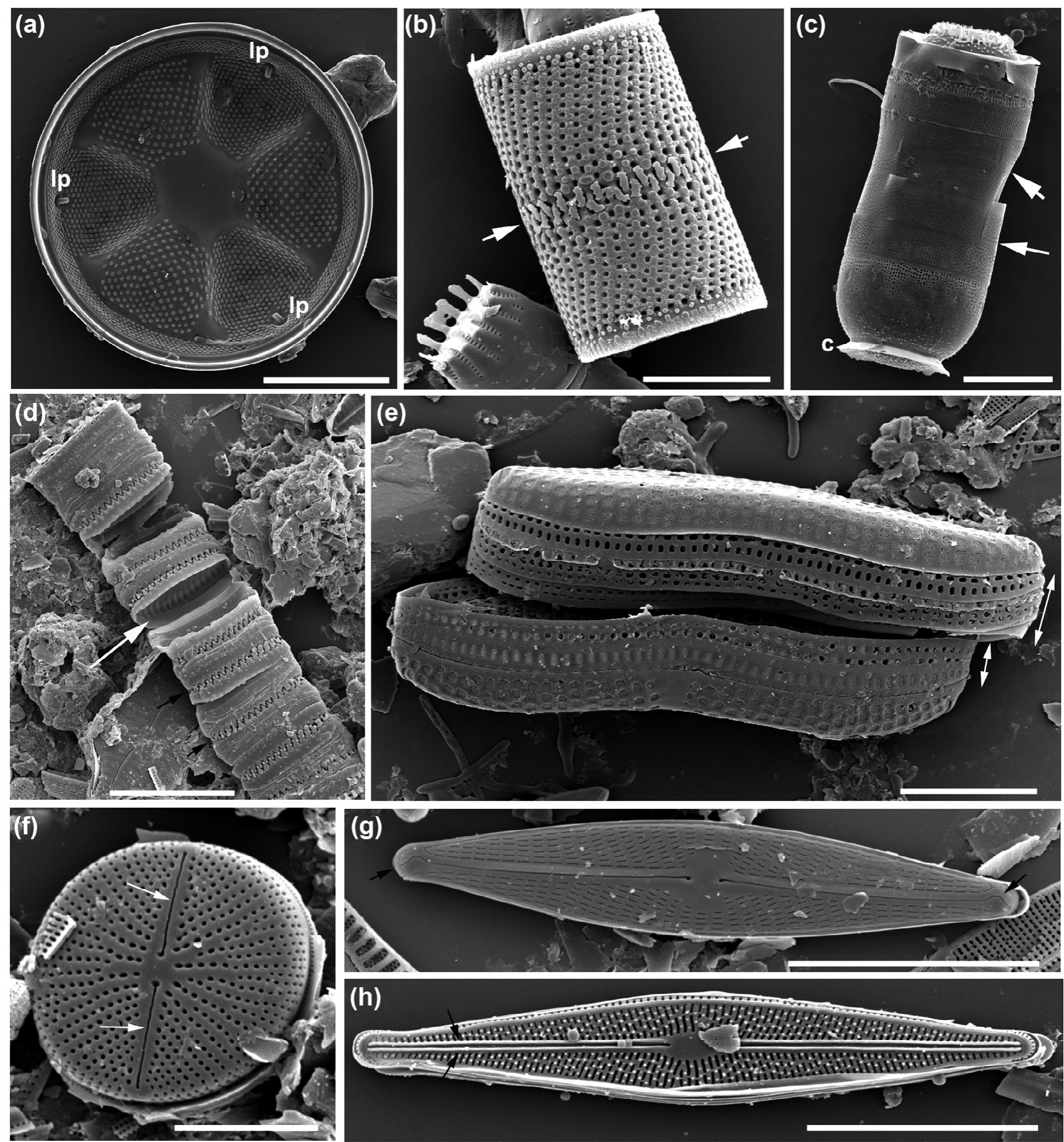

(h)

Fig. 5. Scanning electron micrographs of diatoms to illustrate some of the morphological features. (a) Internal view of whole valve of Actinoptychus, showing valve undulation, radially arranged striae and labiate processes (lp) near the valve margin in alternate sectors. (b) External view of two valves of Aulacoseira, linked by spines (arrow). Pores form spiral striae on the valve mantle. (c) External view of two pairs of cells of Melosira, held together by shared girdle bands (arrows). Valve faces are defined by a corona (c) and have irregular spines at the centre. (d) External view of a chain of Pseudostaurosira cells linked by interlocking spines (black arrows) on sibling valves. Note that some cells have partially opened and the internal structure of the striae is visible (white arrow). (e) External view of two sibling cells of Achnanthes, recent products of mitosis. Note the bands associated with each daughter cell (double-headed arrows) and the cribrate occlusions to the pores in the striae and on the bands. (f) External view of a valve of Cavinula, showing the straight central raphe slits (arrows) and the radial striae comprising round areolae. (g) External view of a cell of Navicula, showing the central raphe slits with hooked polar fissures (arrows), and radiate striae formed of lineate areolae. (h) External view of Brachysira showing central raphe slits flanked by siliceous ribs (arrows) and with a ridge around the valve margin, at the junction of the valve face and mantle. Small knobs of silica are irregularly distributed over the valve face between the radiate striae. Scale bars $5 \mu \mathrm{m}(\mathrm{b}, \mathrm{d}, \mathrm{f})$ and $10 \mu \mathrm{m}(\mathrm{a}, \mathrm{c}, \mathrm{e}, \mathrm{g}, \mathrm{h})$. 
(Fryxell, 1978; Crawford, 1979; Fryxell \& Prasad, 1990), indicates another phenotypic response to the environment, allowing the diatoms to modulate their position in the water column as filament length changes. However, although light regimes have been implicated in the production of linkage valves in Eucampia (Fryxell \& Prasad, 1990) and computer simulations suggest that light regime could control the type of spine production in Aulacoseira (Bentley et al., 2012), there have been no controlled experiments to determine precisely how environmental conditions control the switch from one type of valve production to another.

Studies on populations of single species across a range of environmental conditions can reveal correlations between morphology and environment that may have indicator value. Thus, Cortese \& Gersonde (2007) found that valves of Fragilariopsis kerguelensis (O'Meara) Hustedt were longer and slimmer with more costae in $5 \mu \mathrm{m}$ in warm than cold waters, and suggested that this could be a useful proxy for sea surface temperature. Meanwhile, based on analysis of three sediment cores from different parts of the Southern Ocean, Shukla et al. (2013) suggested that average valve size of this diatom reflects nutrient availability, particularly iron, and could reveal the effects of climate and nutrient cycling in the ocean.

Experimental studies allow cells to be grown under a range of known conditions and can therefore reveal how factors such as salinity and temperature modify morphology (Schultz, 1971; Schmid, 1976; Fryxell, 1988; Syvertsen, 1987; Hausmann \& Lotter, 2001; Balzano et al., 2011; Trobajo et al., 2011). With such information, it then becomes possible to link particular morphs to particular environmental conditions causally (Schmid, 1976; Syvertsen, 1987; Fryxell, 1988; Hausmann \& Lotter, 2001), rather than relying on correlations alone (Hürlimann \& Straub, 1991; Theriot et al., 1988; Cortese \& Gersonde, 2007). Morphology can then be used as a proxy for environmental factors, and applied to past climatic and oceanic change reconstruction (Crosta, 2009; Cortese et al., 2012; Shukla et al., 2013). More dramatic phenotypic plasticity is seen in a few diatoms, e.g. Diadesmis gallica W. Smith, in which the raphe slits are variously reduced or even 'lost'(i.e. completely infilled) when grown in culture, and linking spines are developed around the valve face margin (Granetti, 1977; Cox, 2006). Unfortunately experimental studies have been conducted on only a tiny proportion of diatoms, so we have little idea of the extent to which morphology could be modified in the majority of taxa, or of the potential environmental signals reflected in morphology.

\section{INFERENCES FROM OTHER CONTEMPORARY DIATOM RESEARCH Molecular studies}

The application of molecular techniques to diatoms has revealed genetic diversity, based on sequence differences in targeted genes, within and between clones of traditionally defined taxa, which has in turn stimulated the search for correlated morphological variation. Investigations of Skeletonema costatum Greville sensu lato (Medlin et al., 1991; Sarno et al., 2005; Zingone et al., 2005) resulted in the recognition of five new species, the molecular differences being supported by morphological differences. However, variability in two taxa $(S$. dohrnii Sarno \& Kooistra and $S$. marinoi Sarno \& Zingone) subsequently showed that these could not be separated on morphological grounds (Kooistra et al., 2008).
Investigations of Pseudonitzschia H. Peragallo have also led to a proliferation of new species, discriminated on molecular and morphological grounds, probably stimulated by the potential toxicity of some of those species (Lundholm et al., 2012). In evaluating the significance of sequence differences, some workers suggest that divergence thresholds could be used to determine whether taxa warrant separation at different taxonomic levels (Coleman, 2009; MacGillivary \& Kaczmarska, 2011, 2014), but while defined degrees of difference might be logically attractive, they are intrinsically arbitrary.

\section{Reproductive studies}

Work on the Sellaphora pupula Kützing complex and some other benthic freshwater diatoms (Mann, 1984, 1988, 1989) revealed that within some apparently well-known species, subtle morphological differences reflected breeding patterns. Individual diatoms would only mate with those with the same morphology (assuming both were below the size threshold for sexualization) to produce viable offspring. Building on this work, Mann (1999) argued that reproductively distinguishable strains should be recognized as biological species, eventually formally creating new species for the different taxa (Mann et al., 2004). Further work has revealed that not only can subtle morphological differences indicate different breeding populations, but also that within obligately allogamous populations of diatoms (i.e. where different strains must pair to reproduce), there is discrimination into mating types (Chepurnov et al., 2004; Mann \& Chepurnov, 2005; Vanormelingen et al., 2008).

\section{Biogeography}

Whereas many diatom species were once thought to be cosmopolitan, based on the assumption that micro-organisms could be easily transported ('everything is everywhere'), plus the use of European floras to identify taxa from around the world, resulting in forcefitting taxa (Tyler, 1996), closer examination of specimens from diverse sites has revealed that they are often morphologically distinguishable (Zidarova et al., 2010). Endemism has also been shown for some diatoms (Theriot et al., 2006; Vyverman et al., 2010); others have distinct geographical ranges (Kooistra et al., 2008) and taxa that were once thought to be bipolar are being reassessed (e.g. Van de Vijver et al., 2005). Where molecular analyses have been employed, biogeographical patterns have been revealed for some apparently widespread taxa (Poulícková et al., 2010; Kermarrec et al., 2013), yet widely separated clones of others may share the same genetic identity (Trobajo et al., 2009; Evans et al., 2008, 2009). In other words, individual taxa behave in different ways; some have been able to spread widely, others are much more restricted in their distribution.

\section{DISCUSSION}

Molecular, reproductive and biogeographical studies on diatoms have generated many new taxa that are morphologically more finely discriminated, and almost invariably recognized at the species level. Meanwhile, many diatomists still work primarily with morphology and light microscopy. Yet even here, narrower species concepts are being applied, assuming that subtle morphological discontinuities indicate species differences. In other words, authors are inferring that, if small morphological differences between other taxa can reflect the existence of breeding barriers 
(Droop, 1995; Droop et al., 2000), molecular differences can warrant species-level recognition, or taxa can be geographically restricted, the same must apply to their specimens. Yet they are concluding this merely by inference; they are doing so without independent supporting evidence from molecular, reproductive behaviour or biogeographical studies. Yet on the other hand, it is clear from life history and experimental studies that diatom wall morphology can be significantly modified such that genetically identical individuals (or pre-gametangial and their corresponding post-initial cells) could be identified as different species (Schultz, 1971; Cox, 1985; Trobajo et al., 2006; Rose \& Cox in press).

Studies into the effects of salinity on diatom morphology demonstrate most clearly the flexibility in diatom morphogenesis (and its outcome) (Schultz, 1971; Trobajo et al., 2004, 2011; Balzano et al., 2011). Responses are species-specific (Trobajo et al., 2011) and, in some cases, discriminating between supposed bioindicators becomes problematic (Trobajo et al., 2004). The effects of temperature on diatom morphology have also been clearly demonstrated for a number of marine taxa, e.g. Thalassiosira species (Syvertsen, 1979; Fryxell, 1988). It is, however, impossible to predict, a priori, the morphological range of a particular taxon. Shape analysis can be helpful in determining (a posteriori) whether or not specimens could be part of the same taxon (Stoermer \& Ladewski, 1982; Stoermer et al., 1986; Theriot \& Ladewski, 1986; Rhode et al., 2001; Pappas \& Stoermer, 2003), but perhaps focusing on other morphometric features, such as shapes of central areas and valve apices (Veselá et al., 2009), could improve our understanding of the morphological range of other taxa. It may also provide more reliable taxonomic criteria for species separation and identification.

It is clear that there is considerable genetic diversity within the diatoms, and it is also clear that many previously considered widespread taxa should probably be more finely discriminated, and that finer discrimination would in turn provide useful ecological or biogeographical information. However, there is a danger that every newly discovered variant is being treated as a new species (even if cryptic or pseudo-cryptic); this ignores the fact that genetic diversity is an intrinsic property of any species, allowing for its ability to adapt to different or changing environments and thereby survive.

\section{Diatoms are primarily clonal}

Because diatoms reproduce asexually for most of their life cycle, clonal populations can develop in which a single genotype is represented by many cells, which are likely to show very little morphological variability (other than size-related) at any one time and site under the same environmental conditions. (Fossil populations may show greater variation because they represent accumulations of cells that may have grown under different conditions and may also represent different clonal populations.) When populations from different sites are compared, because each is represented by many, very similar, individuals, it may then be easy to overemphasize the significance of any differences, forgetting that the individuals at each site do not necessarily represent different genotypes. In other words the differences between two populations, each comprising a single genotype, are no more significant than the differences between two individuals, one of each genotype, representing those populations.
In order to obtain sufficient DNA, most molecular studies on diatoms use cultured strains, which again will comprise many cells with the same morphology. Therefore the morphological comparisons will probably involve many individuals in a sample, which similarly may tend to encourage over-emphasis on the significance of any morphological differences observed between those clones. Thus, where sequence differences have been paralleled by morphological variation, the inference has usually been that these represent taxa that warrant (formal) recognition (Medlin et al., 1991; Sarno et al., 2005; Lundholm et al., 2012) and a proliferation of species, cryptic species and pseudo-cryptic species has resulted. But what do these really tell us? Very few studies have investigated the morphological variability of these clones under different conditions; the genetic sequence is linked to a single morphological expression, much as traditional typological taxonomy links the name to a specimen. Furthermore, some of these fine morphological criteria are now being shown to be more variable and therefore unreliable indicators of taxon identity (Kooistra et al., 2008).

\section{Species definitions v. ecological interpretation}

While, in broad terms, the taxonomist seeks to describe and define taxonomic units, using a variety of tools to help discriminate those units, the ecologist is usually seeking to understand how those units respond to, or provide information about, their environment. The question is, to what extent do the units defined by the taxonomist provide consistent information about their biology or ecology? If the discovery of genetic diversity within taxa is leading to a proliferation of names, yet there is little or no physiological or ecological difference between them, how should an ecologist treat them? Is there any relevance (or sense) in giving each genotype a different name? If different morphological forms of the same taxon are given different specific epithets, will the unwitting ecologist record a floristic change if both are encountered at different times, or in different places, rather than understanding that a difference in environment has been reflected in contrasting morphology? Clearly recording that different morphs have been observed provides ecological information, but what is the most appropriate way to do this?

Previously (Cox, 1997), I suggested that if the taxonomic unit 'species' is used only where there is evidence of breeding barriers between populations, 'variety' could be used for within-species populations that are ecologically and morphologically distinct, whereas cases of phenotypic plasticity within species be designated as forms. The latter can then be used to convey ecological information, whether that be salinity, temperature or some other factor. Since we still do not understand patterns of relationship or diversification for the majority of diatoms, and demonstrating sexual compatibility or incompatibility for even a reasonable proportion of diatoms would be a monumental task, it is probably unreasonable to expect a biological species concept (Mann, 1999) to be used for most diatoms. However, expanding the use of varietal and form designations is more practicable, and would help convey ecological and biogeographical information about morphologically similar taxa, where the application of different specific epithets may obscure that. Nevertheless, discrimination of different varieties and forms (not just the use of a species name 'sensu lato') remains necessary if such ecological information is to be conveyed. 


\section{CONCLUSIONS}

The worldwide distribution, ecological diversity and distinctive wall characteristics of diatoms have all contributed to their use as contemporary ecological indicators and also, given their extensive fossil record because of the resistant nature of their silica walls, as palaeo-indicators,. But for any bioindicator system to work effectively, ecological information must be unequivocally linked to reliably identifiable taxonomic units. Traditionally, diatoms have been identified based on the morphology of their silica cell walls under light microscopy. While light microscopy remains the technique of choice for much routine investigation, electron microscopy has revealed both the intricacies of wall construction and also subtle variation within and between classical species. Molecular biology is also uncovering unsuspected genetic diversity within supposedly well-known diatom species, which is being interpreted as evidence of the existence of unrecognized species, cryptic or pseudo-cryptic species. (There is an apparent reluctance by diatomists to use classical infraspecific categories, such as subspecies, variety or form.) But the ecological ranges and tolerances of these new taxa are often unknown and thus their relevance to environmental/palaeoenvironmental research is unclear.

One problem seems to be the continued view of diatoms as static expressions of their genotype, rather than as organisms that can potentially modify their wall morphology in response to their environment. Experimental studies can help us understand the possibilities of, and constraints on, phenotypic responses to particular environmental factors. In turn, this can aid the ecological interpretation of morphological assemblages. Is there real species turnover, or are the same species modifying their morphology in response to environmental change? Reviving the use of forma when morphological change is a response to environment would allow ecological information to be recorded effectively, without suggesting that totally different species are involved. Meanwhile, although they may be challenging and time-consuming, experimental studies into key ecological indicators, in conjunction with genetic studies, are an important way to improve our understanding of species response and adaptation to environment, and thereby to evolutionary processes.

\section{ACKNOWLEDGEMENTS}

This paper is based on an invited talk given at The Micropalaeontology Society Silicofossil Group meeting in Cambridge, August 2013. I would like to thank Claire Allen, Taniel Danelian and Jeremy Young for the invitation to attend that meeting, and for encouraging me to record my thoughts on this topic. I would also like to thank Xavier Crosta and Ric Jordan for their constructive comments on the manuscript.

\section{Manuscript received 8 May 2014 \\ Manuscript accepted 8 May 2014}

Scientific editing by Taniel Danelian

\section{REFERENCES}

Alverson, A.J., Canone, J.J., Gutell, R.R. \& Theriot, E.C. 2006. The evolution of elongate shape in diatoms. Journal of Phycology, 42: 655-668. Amato, A., Orsini, L., D’Alelio, D. \& Montresor, M. 2005. Life cycle, size reduction patterns and ultrastructure of the pennate planktonic diatom Pseudo-nitzschia delicatissima (Bacillariophyceae). Journal of Phycology, 41: 542-556.
Assmy, P., Henjes, J., Smetacek, V. \& Montresor, M. 2006. Auxospore formation by the silica-sinking diatom Fragilariopsis kerguelensis (Bacillariophyceae). Journal of Phycology, 42: 1002-1006.

Bahls, L.L. 2014. Neidiopsis hamiltonii sp. nov., $N$. weilandii sp. nov., $N$. levanderi, and N. wulfii from western North America. Diatom Research, 29: 371-386.

Balzano, S., Kooistra, W.H.C.F. \& Sarno, D. 2011. Effects of salinity on the growth rate and morphology of ten Skeletonema strains. Journal of Plankton Research, 33: 937-945.

Bentley, K., Clack, C. \& Cox, E.J. 2012. Diatom colony formation: a computational study predicts a single mechanism can produce both linkage and separation valves due to an environmental switch. Journal of Phycology, 48: 716-728.

Beszteri, B., Ács, É \& Medlin, L. 2005. Conventional and geometric morphometric studies of valve ultrastructural variation in two closely related Cyclotella species (Bacillariophyta). European Journal of Phycology, 40: $89-103$.

Chepurnov, V.A., Mann, D.G., Sabbe, K. \& Vyverman, W. 2004. Experimental studies on sexual reproduction in diatoms. International Review of Cytology, 237: 91-154.

Cohn, S.A., Spurck, T.P., Pickett-Heaps, J.D. \& Edgar, L.A. 1989. Perizonium and initial valve formation in the diatom Navicula cuspidata (Bacillariophyceae). Journal of Phycology, 25: 15-26.

Coleman, A.W. 2009. Is there a molecular key to the level of 'biological species' in eukaryotes? A DNA guide. Molecular Phylogenetics and Evolution, 50: 197-203.

Cortese, G. \& Gersonde, R. 2007. Morphometric variability in the diatom Fragilariopsis kerguelensis: Implications for Southern Ocean paleoceanography. Earth and Planetary Science Letters, 257: 526-544.

Cortese, G., Gersonde, R., Maschner, K. \& Medley, P. 2012. Glacialinterglacial size variability in the diatom Fragilariopsis kerguelensis: possible iron/dust controls? Paleoceanography, 27: PA 1208, http://dx.doi.org/10.1029/2011PA002187

Cox, E.J. 1975. A reappraisal of the diatom genus Amphipleura Kütz. using light and electron microscopy. British Phycological Journal, 10: $1-12$.

Cox, E.J. 1979. Symmetry and valve structure in naviculoid diatoms. Nova Hedwigia Beihefte, 64: 193-206.

Cox, E.J. 1982. Taxonomic studies on the diatom genus Navicula Bory. IV. Climaconeis Grun., a genus including Okedenia inflexa (Bréb.) Eul. and some members of Navicula sect. johnsoniae sensu Hustedt. British Phycological Journal, 17: 147-168.

Cox, E.J. 1983. Observations on the diatom genus Donkinia Ralfs in Pritchard. II. Frustular studies and intra-specific variation. Botanica Marina, 26: 553-566.

Cox, E.J. 1985. Auxosporulation by a naviculoid diatom and the taxonomic implications. British Phycological Journal, 20: 169-179.

Cox, E.J. 1986. Some taxonomic and ecological considerations of morphological variation within natural populations of benthic diatoms. In Ricard, M. (Ed.), Proceedings of the 8th International Diatom Symposium, Paris 1984. Koeltz, Königstein, 163-172.

Cox, E.J. 1997. Assessing and designating diatom taxa at or below the specific level - a consideration of current status and some suggested guidelines for future use. Nova Hedwigia, 65: 13-26.

Cox, E.J. 2001. What constitutes a stauros? A morphogenetic perspective. In Jahn, R., Witkowski, A. \& Compère, P. (Eds), Festschrift für $H$. Lange-Bertalot. A.R.G. Gantner Verlag K.G., 303-316.

Cox, E.J. 2002. Diatoms - the evolution of morphogenetic complexity in single-celled plants. In Cronk, Q.C.B., Bateman, R.M. \& Hawkins, J.A. (Eds), Developmental Genetics and Plant Evolution. Taylor \& Francis, London, 459-492.

Cox, E.J. 2006. Raphe loss and spine formation in Diadesmis gallica (Bacillariophyta) - an intriguing example of phenotypic plasticity in a diatom. Nova Hedwigia Beiheft, 130: 163-176. 
Cox, E.J. 2011. Morphology, cell wall, cytology, ultrastructure and morphogenetic studies. In Seckbach, J. \& Kociolek, J.P. (Eds), The Diatom World. COLE volume 19. Springer, Dordrecht, 21-45.

Cox, E.J. 2012. Ontogeny, homology and terminology of pennate diatoms -wall morphogenesis as an aid to character state recognition and character state definition for pennate diatom systematics. Journal of Phycology, 48: 1-31.

Cox, E.J. 2013. Recognising and defining taxonomic boundaries in 'wellknown' freshwater diatoms and its relevance to water quality evaluation. Diatomededelingen, 37: 17-26.

Crawford, R.M. 1974. The auxospore wall of the marine diatom Melosira nummuloides (Dillw.) C.Ag. and related species. British Phycological Journal, 9: 9-20.

Crawford, R.M. 1979. Filament formation in the diatom genera Melosira C.A. Agardh and Paralia Heiberg. Nova Hedwigia Beiheft, 64: 121-133.

Crawford, R.M. 1981. Some considerations of size reduction in diatom cell walls. In Ross, R. (Ed.), Proceedings of the Sixth Symposium on Recent and Fossil Diatoms. Koeltz, Königstein, 253-265.

Crosta, X. 2009. Holocene size variations in two diatoms species, East Antarctica: Productivity vs environmental conditions. Deep Sea Research Part I: Oceanographic Research Papers, 56: 1983-1993.

D’Alelio, D., Amato, A., Luedeking, A. \& Montresor, M. 2009. Sexual and vegetative phases in the planktonic diatom Pseudo-nitzschia multistriata. Harmful Algae, 8: 225-232.

Droop, S.J.M. 1995. A morphometric and geographical analysis of two races of Diploneis smithii/D. fusca (Bacillariophyceae) in Britain. In Marino, D. \& Montresor, M. (Eds), Proceedings of the 13th International Diatom Symposium, Italy 1994. Biopress, Bristol, 347-369

Droop, S.J.M., Mann, D.G. \& Lokhorst, G.M. 2000. Spatial and temporal stability of demes in Diploneis smithii/D. fusca (Bacillariophyta) supports a narrow species concept. Phycologia, 39: 527-546.

Evans, K.M., Wortley, A.H., Simpson, G.E., Chepurnov, V.A. \& Mann, D.G. 2008. A molecular systematic approach to explore diversity within the Sellaphora pupula species complex (Bacillariophyta). Journal of Phycology, 44: 215-231.

Evans, K.M., Chepurnov, V.A., Sluiman, H.J., Thomas, S.J., Spears, B.M. \& Mann, D.G. 2009. Highly differentiated populations of the freshwater diatom Sellaphora capitata suggest limited dispersal and opportunities for allopatric speciation. Protist, 160: 386-393.

Fryxell, G.A. 1978. Chain-forming diatoms: Three species of Chaetoceraceae. Journal of Phycology, 14: 62-71.

Fryxell, G.A. 1988. Polymorphism in relation to environmental conditions as exemplified by clonal cultures of Thalassiosira tumida (Janisch) Hasle. In Round, F.E. (Ed.), Proceedings of the 9th International Diatom Symposium, Bristol 1986. Biopress, Bristol, 61-73.

Fryxell, G.A. 1991. Comparison of winter and summer growth stages of the diatom Eucampia antarctica from the Kerguelen plateau and south of the Antarctic convergence zone. Proceedings of the Ocean Drilling Program, Scientific Results, 119: 675-685.

Fryxell, G.A. 1994. Planktonic marine diatom winter stages: antarctic alternatives to resting spores. In Kociolek, J.P. (Ed.), Proceedings of the 11th International Diatom Symposium, San Francisco 1990. California Academy of Sciences, San Francisco, 437-448.

Fryxell, G.A. \& Prasad, A.K.S.K. 1990. Eucampia antarctica var. recta (Mangin) stat. nov. (Biddulphiaceae, Bacillariophyceae): Life stages at the Weddell Sea edge. Phycologia, 29: 27-38.

Geitler, L. 1932. Der Formwechsel der pennaten Diatomeen (Kieselalgen). Archiv für Protistenkunde, 78: 1-226.

Granetti, B. 1977. Variazioni morfologiche, strutturali e biometriche dei frustule di Navicula gallica (W. Smith) Van Heurck coltivata in vitro per alcuni anni. Giornale Botanica Italiana, 112: 227-261.

Hausmann, S. \& Lotter, A.F. 2001. Numerical Cyclotella comensis taxonomy and its importance for quantitative temperature reconstruction. Freshwater Biology, 46: 1323-1333.
Hostetter, H.P. \& Hoshaw, R.W. 1972. Asexual developmental patterns of the diatom Stauroneis anceps in culture. Journal of Phycology, 8: 289-296.

Hürlimann, J. \& Straub, F. 1991. Morphologische und ökologische Charakterisierung von Sippen um den Fragilaria capucina-Komplex sensu Lange-Bertalot 1980. Diatom Research, 6: 21-47.

Hustedt, F. 1955. Zellteilungsfolge und Variabilität bei Diatomeen. Archiv für Mikrobiologie, 21: 391-400.

Jordan, R.W., Ligowski, R., Nöthig, E.-M. \& Priddle, E.J. 1991. The diatom genus Proboscia in Antarctic waters. Diatom Research, 6: 79-107.

Kaczmarska, I., Poulíčková, A., Sato, S., Edlund, M.B., Idei, M., Watanabe, T. \& Mann, D.G. 2013. Proposals for a terminology for diatom sexual reproduction, auxospores and resting stages. Diatom Research, 28: 263-294.

Kaczmarska, I., Mather, L., Luddington, I.A., Muise, F. \& Ehrman, J.M. 2014. Cryptic diversity in a cosmopolitan diatom known as Asterionellopsis glacialis (Fragilariaceae): Implications for ecology, biogeography, and taxonomy. American Journal of Botany, 101: 267-286.

Kermarrec, L., Bouchez, A., Rimet, F. \& Humbert, J.-F. 2013. First evidence of the existence of semi-cryptic species and of a phylogenetic structure in the Gomphonema parvulum (Kützing) Kützing complex (Bacillariophyta). Protist, 164: 686-705.

Kooistra, W.H.C.F., De Stefano, M., Mann, D.G., Salma, N. \& Medlin, L.K. 2003. Phylogenetic position of Toxarium, a pennate-like lineage within centric diatoms (Bacillariophyceae). Journal of Phycology, 39: 185-197.

Kooistra, W.H.C.F., Sarno, D., Balzano, S., Gu, H., Andersen, R.A. \& Zingone, A. 2008. Global diversity and biogeography of Skeletonema species (Bacillariophyta). Protist, 159: 177-193.

Ligowski R., Jordan, R.W. \& Assmy, R. 2012. Morphological adaptation of a planktonic diatom to growth in Antarctic sea ice. Marine Biology, 159: $817-827$.

Lobban, C.S. 1984. Marine tube-dwelling diatoms of Eastern Canada descriptions, checklist and illustrated key. Canadian Journal of Botany, 62: 778-794.

Lundholm, N., Bates, S.S., Baught, K.A., Bill, B.D., Connell, L.B., Léger, C. \& Trainer, V.L. 2012. Cryptic and pseudo-cryptic diversity in diatoms - With descriptions of Pseudo-nitzschia hasleana sp. nov. and $P$. fryxelliana sp. nov. Journal of Phycology, 48: 436-454.

MacGillivary, M.L. \& Kaczmarska, I. 2011. Survey of the efficacy of a short fragment of the $r b c \mathrm{~L}$ gene as a supplemental DNA barcode for diatoms. Journal of Eukaryotic Microbiology, 58: 529-536.

Mann, D.G. 1984. Observations on copulation in Navicula pupula and Amphora ovalis in relation to the nature of diatom species. Annals of Botany, 54: 429-438.

Mann, D.G. 1988. The nature of diatom species: analyses of sympatric populations. In Round, F.E. (Ed.), Proceedings of the Ninth International Diatom Symposium. Koeltz and Biopress, Königstein and Bristol, 293-304.

Mann, D.G. 1989. The species concept in diatom: evidence for morphologically distinct, sympatric gamodemes in four epipelic species. Plant Systematics and Evolution, 164, 215-237.

Mann, D.G. 1999. The species concept in diatoms. Phycologia, 38, 437495.

Mann, D.G. 2011. Size and sex. In Seckbach, J. \& Kociolek, J.P. (Eds), The Diatom World. COLE volume, 19, 145-166. Springer, Dordrecht.

Mann, D.G. \& Chepurnov, V.A. 2005. Auxosporulation, mating system and reproductive isolation in Neidium (Bacillariophyta). Phycologia, 44, 335-350.

Mann, D.G., McDonald, S.K., Bayer, M.M. et al. 2004. The Sellaphora pupula species complex (Bacillariophyceae): Morphometric analysis, ultrastructure and mating data provide evidence for five new species. Phycologia, 43: 459-482.

McBride, S.A. \& Edgar, R.K. 1998. Janus cells unveiled: Frustular morphometric variability in Gomphonema angustatum. Diatom Research, 13: 293-310. 
Medlin, L.K., Elwood, H.J., Stickel, S. \& Sogin, M.L. 1991 Morphological and genetic variation within the diatom Skeletonema costatum (Bacillariophyta): Evidence for a new species, Skeletonema pseudocostatum. Journal of Phycology, 27: 514-524.

Meyer, B. \& Håkansson, H. 1996. Morphological variation of Cyclotella polymorpha sp. nov. (Bacillariophyceae). Phycologia, 45: 64-69.

Pappas, J.L. \& Stoermer, E.F. 2003. Legendre shape descriptors and shape group determination of specimens in the Cymbella cistula species complex. Phycologia, 42: 90-97.

Pickett-Heaps, J., Schmid, A.-A.M.M. \& Edgar, L.A. 1990. The cell biology of diatom valve formation. Progress in Phycological Research, 7: 1-168.

Pocock, K. \& Cox, E.J. 1982. Frustular structure in the diatom Rhabdonema arcuatum (Lyngb.) Kütz. with particular reference to the cingulum as seen with the scanning electron microscope. Nova Hedwigia, 36: 621-641.

Poulícková, A., Veselá, J., Neustupa, J. \& Skaloud, P. 2010. Pseudocryptic diversity versus cosmopolitanism in diatoms: a case study on Navicula cryptocephala Kütz. (Bacillariophyceae) and morphologically similar taxa. Protist, 161: 353-369.

Prasad, A.K.S.K. \& Nienow, J.A. 2006. The centric diatom genus Cyclotella (Stephanodiscaceae: bacillariophyta) from Florida Bay, USA, with special reference to Cyclotella choctawhatcheeana and Cyclotella desikacharyi, a new marine species related to the Cyclotella striata complex. Phycologia, 45: 127-140.

Rhode, K.M., Pappas, J.L. \& Stoermer, E.F. 2001. Quantitative analysis of shape variation in type and modern populations of Meridion (Bacillariophyceae). Journal of Phycology, 37: 175-183.

Rose, D.T. \& Cox, E.J. 2013. Some diatom species do not show a gradual decrease in cell size as they reproduce. Fundamental and Applied Limnology, 182: 117-122.

Rose, D.T. \& Cox, E.J. in press. Is Gomphonema parvulum a good diatom species? Long-term culture studies show that some varieties of G. parvulum belong to other Gomphonema species. Plant Ecology and Evolution.

Round, F.E., Crawford, R.M. \& Mann, D.G. 1990. The Diatoms. Biology and Morphology of the Genera. Cambridge University Press, Cambridge, UK. 747pp.

Sarno, D., Kooistra, W.H.C.F., Medlin, L.K., Percopo, I. \& Zingone, A. 2005. Diversity in the genus Skeletonema (Bacillariophyceae). II. An assessment of the taxonomy of $S$. costatum-like species with the description of four new species. Journal of Phycology, 41: 151-176.

Schmid, A.-M. 1976. Morphologische und physiologische Untersuchungen an Diatomeen des Neusiedlersees: iI. Licht- und rasterelektronenmikroskopische Schalenanalyse der Umweltabhängigen Zyklomorphose von Anomoeoneis sphaerophora (KG.) Pfitzer. Nova Hedwigia, 28: 309-351.

Schmid, A.M.M. 1994. Aspects of morphogenesis and function of diatom cell walls with implications for taxonomy. Protoplasma, 181: 43-60.

Shukla, S.K., Crosta, X., Cortese, G. \& Nayak, G.N. 2013. Climate controlled size variability of diatom Fragilariopsis kerguelensis in the Southern Ocean. Quaternary Science Reviews, 69: 49-68.

Schultz, M.E. 1971. Salinity-related polymorphism in the brackish-water diatom Cyclotella cryptica. Canadian Journal of Botany, 49: 1285-1289.

Steinman, A.D. \& Sheath, R.G. 1984. Morphological variability of Eunotia pectinalis (Bacillariophyceae) in a soft water Rhode Island stream and in culture. Journal of Phycology, 20: 266-276.

Stoermer, E.F. 1967. Polymorphism in Mastogloia. Journal of Phycology, 3: $73-77$.

Stoermer, E.F. \& Ladewski, T.B. 1982. Quantitative analysis of shape variation in type and modern populations of Gomphonema herculaneana. Nova Hedwigia Beiheft, 73: 347-386.

Stoermer, E.F., Ladewski, T.B. \& Kociolek, J.P.. 1986. Further observations on Gomphoneis. In Ricard, M. (Ed.), Proceedings of the 8th International Diatom Symposium, Paris 1984. Koeltz, Königstein, 205-213.
Syvertsen, E.. 1979. Thalassiosira gravida and T. rotula: ecology and morphology. Nova Hedwigia Beiheft, 54: 99-112.

Teubner, K. 1995. A light microscopical investigation and multivariate statistical analyses of heterovalvar cells of Cyclotella-species from lakes of the Berlin-Brandenberg region. Diatom Research, 10: 191-205.

Theriot, E. 1988. An empirically based model of variation in rotational elements in centric diatoms with comments on ratios in phycology. Journal of Phycology, 24: 400-407.

Theriot, E. \& Stoermer, E.F. 1981. Some aspects of morphological variation in Stephanodiscus niagarae (Bacillariophyceae). Journal of Phycology, 17: 64-72.

Theriot, E. \& Ladewski, T.B. 1986. Morphometric analysis of shape of specimens from the neotype of Tabellaria flocculosa (Bacillariophyceae). American Journal of Botany, 73: 224-229.

Theriot, E., Stoermer, E. \& Håkansson, H. 1988. Morphometric analysis of Stephanodiscus alpinus (Bacillariophyceae) and its morphology as an indicator of trophic status. Phycologia, 27: 485-493.

Theriot, E.C., Fritz, S.C., Whitlock, C. \& Conley, D.J. 2006. Late Quaternary rapid morphological evolution of an endemic diatom in Yellowstone Lake, Wyoming. Paleobiology, 32: 38-54.

Trobajo, R., Cox, E.J. \& Quintana, X.D. 2004. An investigation into the effects of some environmental variables on the morphology of Nitzschia frustulum (Bacillariophyta), in relation to its use as bioindicator. Nova Hedwigia, 79: 433-445.

Trobajo, R., Mann, D.G., Chepurnov, V.A., Clavero, E. \& Cox, E.J. 2006. Taxonomy, life cycle and auxosporulation in Nitzschia fonticola. Journal of Phycology, 42: 1353-1372.

Trobajo, R., Clavero, E., Chepurnov, V.A., Sabbe, K., Mann, D.G., Ishihara, S. \& Cox, E.J. 2009. Morphological, genetic, and mating diversity within the widespread bioindicator Nitzschia palea (Bacillariophyta). Phycologia, 48: 443-459.

Trobajo, R., Rovira, L., Mann, D.G. \& Cox, E.J. 2011. Effects of salinity on growth and on valve morphology of five estuarine diatoms. Phycological Research, 59: 83-90.

Tyler, P.A. 1996. Endemism in freshwater algae, with special reference to the Australian region. In Kristiansen, J. (Ed.), Biogeography of freshwater algae. Hydrobiologia, 336: 127-135.

Van de Vijver, B., Gremmen, N.J.M. \& Beyens, L. 2005. The genus Stauroneis (Bacillariophyta) in the Antarctic region. Journal of Biogeography, 32: 1791-1798.

Vanormelingen, P., Chepurnov, V.A., Mann, D.G., Sabbe, K. \& Vyverman, W. 2008. Genetic divergence and reproductive barriers among morphologically heterogeneous sympatric clones of Eunotia bilunaris sensu lato (Bacillariophyta). Protist, 159: 73-90.

Veselá, J., Neustupa, J., Pichrtová, M. \& Poulícková, A. 2009. Morphometric study of Navicula morphospecies (Bacillariophyta) with respect to diatom life cycle. Fottea, 9: 307-316.

Vyverman, W., Verleyen, E., Wilmotte, A. et al. 2010. Evidence for widespread endemism among Antarctic micro-organisms. Polar Science, 4: 103-113.

Werner, P. \& Smol, J.P. 2006. The distribution of the diatom Cyclotella comensis in Ontario (Canada) lakes. Nova Hedwigia Beiheft, 130: 373-392.

Zidarova, R., Van de Vijver, B., Quesada, A. \& de Haan, M. 2010. Revision of the genus Hantzschia (Bacillariophyceae) on Livingston Island (South Shetland Islands, Southern Atlantic Ocean). Plant Ecology and Evolution, 143: 318-333.

Zingone, A., Percopo, I., Sims, P. A. \& Sarno, D. 2005. Diversity in the genus Skeletonema (Bacillariophyceae). I. A re-examination of the type material of Skeletonema costatum, with the description of S. grevillei sp. nov. Journal of Phycology 41: 140-150. 